\title{
Hubungan Tingkat Kecukupan Zat Gizi Dan Siklus Menstruasi Dengan Anemia Pada Remaja Putri
}

\section{The Correlation of Nutrition Adequacy Level and Menstrual Cycle with Anemia Among Adolescent Girls}

\author{
Arnoveminisa Farinendya*1, Lailatul Muniroh², Annas Buanasita ${ }^{3}$
}

\begin{abstract}
ABSTRAK
Latar Belakang: Anemia merupakan salah satu masalah gizi yang rentan terjadi pada remaja putri. Kurangnya asupan zat gizi dan kehilangan darah pada saat menstruasi dapat menjadi penyebab anemia pada remaja putri.

Tujuan: Melakukan analisis korelasi hubungan tingkat kecukupan zat gizi (zat besi, protein, vitamin C, seng) dan siklus menstruasi dengan kejadian anemia pada remaja putri.

Metode: Cross sectional adalah desain penelitian yang digunakan pada penelitian ini. Populasi yang digunakan sebanyak 397 siswi siswi SMAN 3 Surabaya, 206 siswi kelas X dan 191 siswi kelas XI. Besar sampel sebanyak 78 orang dipilih secara proportional random sampling dari kelas $\mathrm{X}$ sebanyak 40 siswi dan kelas $\mathrm{XI}$ sebanyak 38 siswi. Data tingkat kecukupan zat gizi didapatkan melalui kuesioner SQ-FFQ dan dibandingkan dengan Angka Kecukupan Gizi (AKG). Data siklus menstruasi didapatkan melalui kuesioner terstruktur. Data anemia didapatkan dari pemeriksaan kadar hemoglobin dengan menggunakan alat hemoglobinometer digital (easy touch). Analisis statistik menggunakan uji korelasi chi-square.

Hasil: Tingkat kecukupan protein $(p=0,031)$ dan vitamin $C(p=0,020)$ berhubungan dengan anemia. Tingkat kecukupan zat besi $(p=0,416)$, seng $(p=0,392)$, dan siklus menstruasi $(p=0,731)$ tidak berhubungan dengan anemia.

Kesimpulan: Remaja putri yang memiliki tingkat kecukupan protein dan vitamin $\mathrm{C}$ cukup akan menurunkan risiko terkena anemia. Oleh karena itu, remaja putri dianjurkan untuk mempertahankan asupan protein dan vitamin $\mathrm{C}$ untuk mencegah kejadian anemia.
\end{abstract}

Kata Kunci: anemia, siklus menstruasi, remaja putri, protein, vitamin C.

\section{ABSTRACT}

Background: Anemia is nutrition problem that risk in adolescent girls. Anemia can be caused by lack of nutrition and blood loss when menstruation.

Objective: Analyze the correlation nutrition adequacy level (iron, protein, vitamin C, zinc) and menstrual cycle with anemia in adolescent girls.

Methods: Cross sectional design was the design used in this research. The population was 397 subjects' female students in Senior High School 3 Surabaya, 206 subjects' grade X and 191 subjects grade XI. The sample studied was 78 subjects selected by proportional random sampling of grade $X 40$ subjects and grade XI 38 subjects. The nutrition adequacy level data was obtained by Semi Quantitative Food Frequency Questionnaires (SQ-FFQ) and compared to Recommended Dietary Allowances (RDA). The data menstrual cycle was gained by structured questionnaires. Data of anemia was gained by hemoglobin concentration which measured by digital hemoglobinometer (easy touch). The statistical test used chi square test.

Result: Protein adequacy level $(p=0.031)$ and vitamin $C(p=0.020)$ were relationship with anemia. Iron adequacy level $(p=0.416)$, zinc ( $p=0.392)$, and menstrual cycle $(p=0.731)$ were no relationship with anemia.

Conclusion: Adolescent girls who had adequate intake of protein and vitamin $C$ will reduce the risk of anemia. Therefore, adolescense girls are encouraged to maintain intake of protein and vitamin C to prevent anemia.

Keywords: anemia, menstrual cycle, adolescent girls, protein, vitamin C.

Koresponden: arnoveminisa.farinendya-2015@fkm.unair.ac.id

1,2Departemen Gizi Kesehatan, Fakultas Kesehatan Masyarakat, Universitas Airlangga

${ }^{3}$ Akademi Gizi Surabaya

(C)2019. Farinendya, dkk. Open access under CC BY - SA license.

Received: 11-07-2019, Accepted: 19-08-2019, Published online: 27-12-2019.

doi: 10.20473/amnt.v3.i4.2019 298-304, Joinly Published by IAGIKMI \& Universitas Airlangga 


\section{PENDAHULUAN}

Adolescence atau masa remaja atau adalah masa berlangsungnya perubahan seperti pertumbuhan fisik, kognitif, dan psikososial yang berlangsung secara cepat. Usia remaja adalah usia pergantian dari kanak-kanak menuju dewasa ${ }^{1}$. Anemia dapat terjadi pada kelompok remaja terutama pada remaja putri. Hal ini dikarenakan remaja putri berada dalam masa pertumbuhan dan mengalami menstruasi setiap bulannya sehingga terjadi kehilangan zat besi². Selama menstruasi remaja mengalami pengeluaran darah yang banyak. Seiring dengan pengeluaran darah maka zat besi pada darah juga ikut hilang sebanyak 5\%-10\% sehingga menyebabkan defisiensi zat besi. Hal inilah yang membuat remaja putri yang mengalami siklus menstruasi tidak normal rentan terkena anemia ${ }^{3}$.

Anemia merupakan kondisi seseorang dengan kadar hemoglobin kurang dari standar. Pada remaja putri apabila kadar hemoglobin dalam darah $<12 \mathrm{~g} / \mathrm{dL}$ akan menderita anemia ${ }^{4}$. Anemia pada remaja putri dapat disebabkan oleh kekurangan zat besi, kekurangan vitamin B seperti B9 dan B12, penyakit infeksi kronis, dan genetik. Selain itu, menstruasi setiap bulan mempengaruhi terjadinya anemia pada remaja putri ${ }^{5}$.

Kurangnya asupan zat besi merupakan penyebab utama terjadinya anemia pada remaja putri, namun hal ini juga dipengaruhi oleh kemampuan penyerapan zat besi baik yang memudahkan maupun yang menghambat ${ }^{6}$. Protein dan vitamin $\mathrm{C}$ adalah zat gizi yang berperan sebagai enhancer zat besi. Fitat, tanin, oksalat, dan kalsium adalah zat gizi yang berperan sebagai inhibitor zat besi ${ }^{7}$.

Selain kurangnya asupan zat besi, siklus menstruasi juga mempengaruhi kejadian anemia. Menstruasi adalah perubahan fisiologis yang dipengaruhi oleh hormon dan terjadi dalam tubuh wanita secara berkala ${ }^{8}$. Siklus menstruas merupakan jarak seseorang mengalami menstruasi pada waktu lalu dengan menstruasi berikutnya ${ }^{9}$. Anemia dapat terjadi pada remaja putri apabila mengalami siklus menstruasi pendek ( $<21$ hari) karena dapat menyebabkan jumlah darah yang keluar lebih banyak ${ }^{10}$.

Kejadian anemia di Indonesia sebesar $21,7 \%$ dengan prevalensi wanita mencapai $23,9 \%$ lebih tinggi daripada lakilaki sebesar $18,4 \%^{11}$. Kejadian anemia di Surabaya khususnya pada remaja putri mencapai $33,3 \%^{12}$, sedangkan prevalensi anemia pada siswa SMP dan SMA di Kota Surabaya mencapai $26,5 \%^{13}$. Apabila kejadian anemia $>20 \%$ menunjukkan bahwa anemia menjadi permasalahan gizi di Indonesia ${ }^{11}$. Salah satu sekolah yang memiliki kejadian anemia $>20 \%$ adalah SMAN 3 Surabaya yaitu sebesar $51,79 \%^{14}$. Tingginya angka kejadian anemia di SMAN 3 Surabaya merupakan alasan pentingnya penelitian ini dilakukan untuk mengurangi risiko terjadinya anemia pada remaja putri.

SMAN 3 Surabaya merupakan sekolah yang terletak di Jalan Memet Sastrowiryo Kompleks TNI AL Kenjeran, Surabaya Utara. Sekolah ini memiliki 3 jurusan yaitu MIPA, IPS, dan IBB. Pada tahun 2016 SMAN 3 Surabaya pernah dijadikan tempat penelitian tentang anemia dan didapatkan sebanyak 51,79\% siswi mengalami anemia. Tujuan penelitian adalah menganalisis hubungan tingkat kecukupan zat gizi dan siklus menstruasi dengan kejadian anemia pada remaja putri di SMAN 3 Surabaya.

\section{METODE}

Penelitian ini menggunakan desain penelitian cross sectional. Populasi yang digunakan adalah siswi di SMAN 3 Surabaya kelas X (206 siswi) dan kelas XI (191 siswi) sehingga total populasi sebanyak 397 siswi. Penentuan sampel menggunakan rumus Lemeshow sehingga didapatkan sampel sebanyak 78 siswi $^{15}$. Teknik pengambilan sampel menggunakan proportional random sampling dengan besar sampel kelas X 40 siswi dan kelas XI 38 siswi. Sampel yang diteliti adalah siswi yang memenuhi kriteria inklusi meliputi sudah mengalami menstruasi, tidak sedang berpuasa pada saat pengambilan data, tidak sedang menstruasi pada saat pengambilan data, dan tidak sedang menjalani diet khusus.

Pada penelitian ini menggunakan data primer yang didapatkan dengan melakukan pemeriksaan untuk mengetahui kadar hemoglobin dengan menggunakan alat hemoglobinometer digital (easy touch) yang dilakukan oleh bidan serta dengan melakukan wawancara secara langsung kepada responden. Data primer yang digunakan meliputi kuesioner karakteristik responden (usia, pengetahuan gizi, uang saku), karakteristik orangtua (pendidikan, pekerjaan, pendapatan), asupan makanan, dan siklus menstruasi. Kuesioner karakteristik responden ditanyakan melalui wawancara kuesioner terstruktur. Pengetahuan gizi responden diklasifikasikan menjadi kurang apabila jawaban benar $<60 \%$, cukup apabila jawaban benar $60-80 \%$, baik apabila jawaban benar $>80 \%{ }^{16}$. Uang saku responden diklasifikasikan menjadi kuartil 1, kuartil 2, kuartil 3, dan kuartil 4). Kuesioner karakteristik orangtua ditanyakan dengan menggunakan kuesioner. Pendidikan orangtua diklasifikasikan menjadi dasar jika tamat SD/MI/SMP/MTs sederajat, menengah jika tamat SMA/MA/SMK/MAK sederajat, dan tinggi jika tamat perguruan tinggi. Pendapatan orangtua diklasifikasikan menjadi kuartil 1, kuartil 2, kuartil 3, dan kuartil 4. Data asupan makanan dilakukan wawancara dengan menggunakan instrumen Semi Quantitative Food Frequency Questionnaire (SQ-FFQ). Pada instrumen SQ-FFQ terdapat kelompok makanan pokok, protein hewani, protein nabati, sayuran, minyak, produk susu dan hasil olahannya, serta lain-lain sehingga total terdapat 66 bahan makanan. SQFFQ merupakan modifikasi dari penelitian yang telah ada sehingga tidak dilakukan validasi. Hasil wawancara SQ-FFQ diolah menggunakan software Nutrisurvey sehingga didapatkan asupan zat besi, protein, vitamin C, dan seng. Kemudian dibandingkan dengan Angka Kecukupan Gizi (AKG) dan dikategorikan menjadi cukup apabila tingkat kecukupan zat gizi $\geq 77 \%$ nilai AKG dan kurang apabila tingkat kecukupan zat gizi $<77 \%$ nilai $A K G^{17}$. Data siklus menstruasi diperoleh dari wawancara menggunakan kuesioner dalam rentang 2 bulan terakhir. Pengkategorian siklus menstruasi menjadi normal (21-35 hari) dan tidak normal $(<21$ hari atau $>35$ hari) ${ }^{8}$. Selain itu, data sekunder meliputi gambaran umum sekolah dan daftar nama siswi SMAN 3 Surabaya yang diperoleh dari bagian Tata Usaha.

Pengujian tingkat kecukupan zat gizi dengan anemia menggunakan uji chi square. Pengujian variabel siklus menstruasi dengan anemia menggunakan uji chi square. Penelitian ini telah lolos etik penelitian dari Komite Etik FKM Unair dengan nomor 109/EA/KEPK/2019. 


\section{HASIL DAN PEMBAHASAN}

\section{Karakteristik Responden}

Responden yang diambil adalah remaja putri kelas $X$ dan kelas XI. Berdasarkan Tabel 1 menunjukkan sebanyak 77\% responden berusia 16 tahun. Usia 16 tahun termasuk dalam remaja akhir ${ }^{18}$. Tingkat kematangan dan kekuatan seseorang akan lebih matang dalam berfikir apabila semakin cukup umur. Hal ini dapat menyebabkan remaja lebih memperhatikan asupan makanan yang bergizi, sehingga dapat mengurangi risiko terkena anemia gizi.
Pengetahuan gizi diperoleh dari hasil wawancara kuesioner kepada responden. Sebanyak 63\% responden memiliki pengetahuan gizi cukup. Penerapan pengetahuan gizi dalam memilih makanan dapat memenuhi kebutuhan gizinya apabla seseorang memiliki pengetahuan gizi yang baik $^{19}$.

Uang saku akan mempengaruhi daya beli makanan untuk dikonsumsi. Sebagian besar responden (47\%) memiliki uang saku pada kategori kuartil 2 (>Rp. 16.250-27.500). Remaja yang memiliki uang jajan kurang berpeluang untuk mengalami kekurangan zat gizi besi apabila dibandingkan remaja putri dengan uang jajan cukup ${ }^{20}$.

Tabel 1. Karakteristik Responden dan Orangtua

\begin{tabular}{|c|c|c|}
\hline Karakteristik Responden dan Orangtua Responden & Jumlah (n) & Persentase (\%) \\
\hline \multicolumn{3}{|l|}{ ( } \\
\hline 16 tahun & 60 & 77 \\
\hline 17 tahun & 18 & 23 \\
\hline \multicolumn{3}{|l|}{ Pengetahuan Gizi } \\
\hline Kurang $(<60 \%)$ & 25 & 32 \\
\hline Cukup $(60-80 \%)$ & 49 & 63 \\
\hline Baik (>80\%) & 4 & 5 \\
\hline \multicolumn{3}{|l|}{ Uang Saku } \\
\hline Rp. 5.000-16.250 & 23 & 30 \\
\hline$>$ Rp. $16.250-27.500$ & 37 & 47 \\
\hline > Rp. 27.500-38.750 & 8 & 10 \\
\hline > Rp. 38.750-50.000 & 10 & 13 \\
\hline \multicolumn{3}{|l|}{ Pendidikan Ayah } \\
\hline Dasar (Tamat SD/MI/SMP/MTs sederajat) & 7 & 9 \\
\hline Menengah (Tamat SMA/MA/SMK/MAK sederajat) & 43 & 55 \\
\hline Tinggi (Tamat perguruan tinggi) & 28 & 36 \\
\hline \multicolumn{3}{|l|}{ Pendidikan Ibu } \\
\hline Dasar (Tamat SD/MI/SMP/MTs sederajat) & 14 & 18 \\
\hline Menengah (Tamat SMA/MA/SMK/MAK sederajat) & 41 & 53 \\
\hline Tinggi (Tamat perguruan tinggi) & 23 & 29 \\
\hline \multicolumn{3}{|l|}{ Pekerjaan Ayah } \\
\hline ASN & 3 & 4 \\
\hline Karyawan & 40 & 52 \\
\hline TNI/Polri & 6 & 8 \\
\hline Wiraswasta & 20 & 25 \\
\hline Nelayan & 1 & 1 \\
\hline Tidak Bekerja & 8 & 10 \\
\hline Lainnya & 0 & 0 \\
\hline \multicolumn{3}{|l|}{ Pekerjaan Ibu } \\
\hline ASN & 0 & 0 \\
\hline Karyawan & 10 & 13 \\
\hline TNI/Polri & 0 & 0 \\
\hline Wiraswasta & 14 & 18 \\
\hline Nelayan & 0 & 0 \\
\hline Tidak Bekerja & 50 & 64 \\
\hline Lainnya & 4 & 5 \\
\hline \multicolumn{3}{|l|}{ Pendapatan Orangtua } \\
\hline Rp. 500.000-3.125.000 & 34 & 44 \\
\hline Rp. 3.125.000-5.750.000 & 27 & 35 \\
\hline Rp. 5.750.000-8.375.000 & 14 & 18 \\
\hline Rp. 8.375.000-11.000.000 & 3 & 3 \\
\hline
\end{tabular}

Berdasarkan tabel 2 maka dapat diketahui bahwa ratarata asupan zat gizi responden yang telah memenuhi AKG adalah vitamin C. Rata-rata asupan protein hampir memenuhi AKG dan rata-rata asupan zat besi serta seng belum memenuhi AKG. Berdasarkan tabel 3 maka dapat diketahui mayoritas responden memiliki tingkat kecukupan zat besi kurang (97\%), protein cukup (58\%), vitamin C cukup (62\%), dan seng kurang (97\%). 
Berdasarkan tabel 4 maka dapat diketahui mayoritas responden memiliki status tidak anemia (76\%). Responden yang diambil merupakan responden yang telah memenuhi kriteria inklusi, sehingga responden yang mengalami anemia lebih sedikit daripada yang tidak mengalami anemia.

\section{Karakteristik Orangtua}

Pemilihan makanan keluarga dapat ditentukan dari pendidikan orangtua karena pendidikan orangtua merupakan modal menentukan pengetahuan, sikap, dan keterampilannya. Sebagian besar pendidikan ayah responden (55\%) dan ibu responden (53\%) dalam kategori menengah (Tamat SMA/MA/SMK/MAK sederajat). Kualitas hidangan yang disajikan dapat dipengaruhi oleh pendidikan dan pengetahuan ibu. Apabila pengetahuan ibu semakin baik maka sikap ibu terhadap kualitas gizi makanan semakin positif sehingga asupan gizi keluarga semakin baik ${ }^{20}$.

Status pekerjaan orangtua secara tidak langsung akan mempengaruhi anemia pada remaja putri. Sebagian besar ayah responden bekerja sebagai karyawan (52\%) dan ibu responden tidak bekerja (64\%). Pekerjaan orangtua akan mempengaruhi besarnya pendapatan.

Pendapatan orangtua akan berhubungan dengan daya beli dan pemilihan bahan makanan keluarga. Sebagian besar orangtua responden (44\%) memiliki pendapatan pada kuartil
1 (Rp. 500.000-3.125.000). Rata-rata pendapatan orangtua adalah sebesar Rp. 3.396.794, sedangkan UMK di Kota Surabaya Tahun 2019 mencapai Rp. 3.871.052. Hal ini menunjukkan bahwa rata-rata pendapatan orangtua responden masih di bawah UMK Kota Surabaya.

\section{Hubungan Antar Variabel}

Berdasarkan Tabel 5 dapat diketahui bahwa hasil $p$ value 0,416 sehingga tingkat kecukupan zat besi dengan anemia pada remaja putri tidak berhubungan. Asupan zat besi pada mayoritas responden yang masih kurang dapat dilihat pada Tabel 2, sehingga tingkat kecukupan sebagian besar responden juga kurang (97\%). Mayoritas responden yang memiliki asupan zat besi kurang dapat menjadi dalah satu penyebab tidak adanya hubungan tingkat kecukupan zat besi dan anemia. Namun, anemia bisa disebabkan oleh zat gizi lainnya. Kadar zat besi di hati dapat dipengaruhi oleh kurangnya asupan zat besi. Apabila cadangan zat besi di hati habis maka lama kelamaan akan mempengaruhi kadar hemoglobin sehingga menyebabkan anemia. Hal ini sesuai dengan penelitian Akib dan Sumarmi tahun 2017 bahwa tidak ada hubungan antara asupan zat besi dengan status $\mathrm{Hb}$, dikarenakan responden lebih suka mengonsumsi protein nabati (zat besi non heme) sehingga dapat menyebabkan penyerapan zat besi tidak sempurna ${ }^{21}$.

Tabel 2. Asupan Zat Gizi Responden

\begin{tabular}{lrrrr}
\multicolumn{1}{c}{ Zat Gizi } & Rata-rata & Standar Deviasi & Minimum & Maksimum \\
\hline Energi (kkal) & 1575,7 & $\pm 360,8$ & 889,9 & 2419,1 \\
Zat Besi (mg) & 8,9 & $\pm 4,7$ & 3,5 & 25,0 \\
Protein (g) & 54,8 & $\pm 21,2$ & 26,2 & 121,5 \\
Vitamin C (mg) & 116,1 & $\pm 104,0$ & 8,3 & 470,0 \\
Seng (mg) & 6,1 & $\pm 1,9$ & 2,9 & 11,2 \\
\hline
\end{tabular}

Berdasarkan Tabel 5 maka dapat diketahui bahwa hasil $p$ value 0,031 antara tingkat kecukupan protein dan anemia, sehingga ada hubungan tingkat kecukupan protein dengan kejadian anemia pada remaja putri. Rata-rata konsumsi potein responden telah sesuai dengan anjuran AKG dapat dilihat pada Tabel 2. Responden mengonsumsi sumber protein seperti telur ayam, ayam, hati ayam, ikan mujahir, dan kerang. Meskipun terdapat beberapa bahan makanan yang tidak dikonsumsi seperti bebek, ikan bandeng, dan kepiting, namun masih terdapat bahan makanan dengan harga terjangkau. Penelitian ini sejalan dengan penelitian
Pratiwi pada tahun 2016 dan Solicha pada tahun 2018 yang menunjukkan asupan protein dan anemia pada remaja putri berhubungan. Asupan protein yang cukup akan membantu proses transportasi zat besi untuk pembentukan hemoglobin sehingga tidak terjadi kekurangan zat besi yang akan menyebabkan anemia ${ }^{20}$. Responden memiliki asupan protein yang masih kurang. Apabila asupan protein kurang maka penyerapan zat besi di dalam tubuh akan terhambat dan lama kelamaan akan menimbulkan kekurangan zat besi. Responden lebih sering mengonsumsi protein nabati yang lebih murah dan lebih mudah didapatkan di kantin sekolah ${ }^{22}$.

Tabel 5. Hasil Analisis Hubungan Tingkat Kecukupan Zat Gizi Responden

\begin{tabular}{|c|c|c|c|c|c|c|c|}
\hline \multirow{3}{*}{$\begin{array}{l}\text { Tingkat Kecukupan Zat } \\
\text { Gizi }\end{array}$} & \multicolumn{4}{|c|}{ Kejadian Anemia } & \multirow{2}{*}{\multicolumn{2}{|c|}{ Total }} & \multirow{3}{*}{$p$-value } \\
\hline & \multicolumn{2}{|c|}{ Anemia } & \multicolumn{2}{|c|}{ Tidak Anemia } & & & \\
\hline & $\mathrm{n}$ & $\%$ & $n$ & $\%$ & $n$ & $\%$ & \\
\hline \multicolumn{8}{|l|}{ Zat Besi } \\
\hline Cukup & 0 & 0 & 2 & 3 & 0 & 3 & \multirow{2}{*}{0,416} \\
\hline Kurang & 19 & 24 & 57 & 73 & 76 & 97 & \\
\hline \multicolumn{8}{|l|}{ Protein } \\
\hline Cukup & 15 & 19 & 30 & 39 & 45 & 58 & \multirow{2}{*}{$0,031^{*}$} \\
\hline Kurang & 4 & 5 & 29 & 37 & 33 & 42 & \\
\hline \multicolumn{8}{|l|}{ Vitamin C } \\
\hline Cukup & 16 & 21 & 32 & 41 & 48 & 62 & \multirow{2}{*}{$0,020 *$} \\
\hline Kurang & 3 & 4 & 27 & 34 & 30 & 38 & \\
\hline \multicolumn{8}{|l|}{ Seng } \\
\hline Cukup & 1 & 1 & 1 & 1 & 2 & 2 & \multirow{2}{*}{0,392} \\
\hline Kurang & 18 & 23 & 58 & 75 & 76 & 98 & \\
\hline
\end{tabular}

*signifikan $p<0,05$ 
Vitamin C merupakan fasilitator absorbsi zat besi yang paling umum yang dapat membantu penyerapan zat besi non heme empat kali lipat ${ }^{20}$. Berdasarkan Tabel 5 maka dapat diketahui bahwa hasil $p$ value 0,020 sehingga ada hubungan tingkat kecukupan vitamin $C$ dengan anemia pada remaja putri di SMAN 3 Surabaya. Responden mengonsumsi bahan makanan sumber vitamin $C$ dalam jumlah yang cukup. Bahan makanan yang dikonsumsi merupakan bahan makanan yang mudah didapatkan dan memiliki harga yang terjangkau. Berdasarkan tabel 3 sebagian responden memiliki tingkat kecukupan vitamin C cukup (62\%). Adanya vitamin C dapat mereduksi zat besi ferri menjadi ferro yang lebih mudah diserap dalam tubuh, sehingga penyerapan zat besi non heme akan lebih mudah diserap. Asupan vitamin $\mathrm{C}$ yang tinggi akan menurunkan anemia karena kadar hemoglobin semakin tinggi pula $^{20}$. Penelitian Pradanti, dkk pada tahun 2015 juga menyebutkan bahwa asupan vitamin $\mathrm{C}$ dengan kadar hemoglobin berhubungan. Responden yang mengonsumsi vitamin C kategori normal tidak mengalami anemia. Namun, terdapat juga responden yang mengonsumsi vitamin $\mathrm{C}$ kategori defisit berat. Kekurangan asupan vitamin $C$ disebabkan oleh kurangnya konsumsi bahan makanan sumber vitamin $C$, selain itu responden tidak mengonsumsi tablet vitamin $\mathrm{C}$. Vitamin $\mathrm{C}$ yang berperan sebagai enhancer akan memudahkan penyerapan zat besi sehingga tidak terjadi anemia ${ }^{6}$.

Tabel 3. Tingkat Kecukupan Zat Gizi Responden

\begin{tabular}{ccc}
\hline Kecukupan Zat Gizi & Jumlah (n) & Persentase (\%) \\
\hline Energi & & \\
Kurang & 46 & 59 \\
Cukup & 32 & 41 \\
Zat Besi (Fe) & & \\
Kurang & 76 & 97 \\
Cukup & 2 & 3 \\
Protein & & \\
Kurang & 33 & 42 \\
Cukup & 45 & 58 \\
Vitamin C & & \\
Kurang & 30 & 38 \\
Cukup & 48 & 62 \\
Seng (Zn) & & \\
Kurang & 76 & 97 \\
Cukup & 2 & 3 \\
\hline
\end{tabular}

Zat gizi yang dapat mempengaruhi penyerapan zat besi adalah seng. Seng berperan dalam proses sintesis protein termasuk protein pengangkut besi, yaitu transferin. Apabila seng di dalam tubuh berlebihan maka akan menurunkan zat besi dalam tubuh. Berdasarkan tabel 3 maka dapat diketahui bahwa sebanyak $97 \%$ responden memiliki tingkat kecukupan seng yang masih kurang. Hasil $p$ value 0,392 yang menunjukkan bahwa tidak ada hubungan tingkat kecukupan seng dengan anemia pada remaja putri di SMAN 3 Surabaya. Penelitian Sahana dan Sumarmi pada tahun 2015 menyebutkan bahwa tidak ada hubungan asupan seng dan anemia ${ }^{23}$. Bahan makanan yang dikonsumsi oleh responden merupakan bahan makanan yang memiliki kandungan seng rendah seperti kacang hijau, kacang tanah, dan kacang merah. Penelitian Fitrah menunjukkan bahwa seluruh responden memiliki asupan tingkat kecukupan seng kategori kurang.

Tabel 4. Siklus Menstruasi Responden

\begin{tabular}{llc}
\hline Kategori Siklus Menstruasi & Jumlah $(\mathrm{n})$ & Persentase $(\%)$ \\
\hline Normal (21-35 hari) & 68 & 87 \\
Tidak normal (<21 hari atau & 10 & 13 \\
$>35$ hari) & 78 & 100 \\
\hline Total & & \\
\hline
\end{tabular}

Apabila asupan seng tinggi maka akan mengurangi penyerapan zat besi dan menyebabkan zat besi yang tersimpan dalam tubuh berkurang. Sebaliknya apabila asupan seng rendah maka penyerapan zat besi dalam tubuh akan optimal24. Oleh karena itu, responden disarankan untuk mengonsumsi bahan makanan dari kelompok hewani seperti ayam, sapi, ikan, udang, dan kepiting. Faktor lain yang dapat menyebabkan anemia adalah siklus menstruasi. Anemia dapat dipengaruhi oleh banyaknya darah yang keluar karena remaja putri tidak memiliki persediaan zat besi yang cukup, sehingga tidak dapat menggantikan zat besi yang hilang selama menstruasi ${ }^{3}$. Berdasarkan Tabel 5 maka dapat diketahui bahwa hasil $p$ value 0,731 yang berarti tidak ada hubungan siklus menstruasi dengan kejadian anemia pada remaja putri di SMAN 3 Surabaya. Berdasarkan Tabel 4 dapat diketahui sebanyak $87 \%$ responden mengalami siklus menstruasi normal. Siklus menstruasi yang normal akan menyebabkan seseorang kehilangan darah lebih sedikit daripada seseorang yang mengalami siklus menstruasi tidak normal. Siklus menstruasi pada kategori tidak normal memungkinkan untuk kehilangan darah yang diikuti dengan kehilangan zat besi dan menyebabkan anemia ${ }^{22}$

Tabel 6. Hasil Analisis Hubungan Siklus Menstruasi Responden

\begin{tabular}{|c|c|c|c|c|c|c|c|}
\hline \multirow{3}{*}{ Siklus Menstruasi } & \multicolumn{4}{|c|}{ Kejadian Anemia } & \multirow{2}{*}{\multicolumn{2}{|c|}{ Total }} & \multirow{3}{*}{$p$-value } \\
\hline & \multicolumn{2}{|c|}{ Anemia } & \multicolumn{2}{|c|}{ Tidak Anemia } & & & \\
\hline & $\mathrm{n}$ & $\%$ & $\mathrm{n}$ & $\%$ & $\mathrm{n}$ & $\%$ & \\
\hline Normal & 17 & 22 & 51 & 65 & 68 & 87 & \multirow{2}{*}{0,731} \\
\hline Tidak Normal & 2 & 3 & 8 & 10 & 10 & 13 & \\
\hline
\end{tabular}

*signifikan $\mathrm{p}<0,05$

Banyaknya darah yang keluar akan berpengaruh pada anemia. Volume darah yang keluar setiap bulannya sekitar 30-50 cc. Hal ini dapat membuat seseorang kehilangan 12-15 $\mathrm{mg}$ zat besi per bulan atau sekitar 0,4-0,5 mg per hari selama 28-30 hari ${ }^{25}$. Penelitian ini sesuai dengan penelitian Shariff pada tahun 2018 yang menunjukkan tidak ada hubungan siklus menstruasi dengan status anemia. Sebanyak $65,5 \%$ responden mengalami siklus menstruasi yang normal. 
Banyaknya darah yang keluar akan berpengaruh pada kejadian anemia. Responden yang mengalami siklus menstruasi normal masih memiliki persediaan zat besi sebagai pengganti zat besi yang telah hilang selama menstruasi berlangsung sehingga tidak terjadi anemia ${ }^{26}$. Apabila terjadi kehilangan zat besi saat menstruasi maka responden disarankan mengonsumsi makanan yang mengandung zat besi agar kadar $\mathrm{Hb}$ meningkat sehingga terhindar dari anemia.

\section{KESIMPULAN}

Hasil penelitian diperoleh asupan protein dan vitamin $C$ telah memenuhi AKG dan asupan zat besi serta seng belum memenuhi AKG. Sebagian besar responden memiliki tingkat kecukupan cukup pada protein (58\%) dan vitamin C (62\%), sedangkan tingkat kecukupan kurang pada zat besi (97\%) dan seng $(97 \%)$. Sebagian besar responden mengalami siklus menstruasi normal (95\%). Selain itu, dapat diketahui bahwa tingkat kecukupan protein $(p=0,031)$ dan vitamin $C(0,020)$ dengan kejadian anemia pada remaja putri berhubungan, serta tingkat kecukupan zat besi $(p=0,416)$, seng $(0,392)$, dan siklus menstruasi $(p=0,731)$ dengan kejadian anemia pada remaja putri tidak ditemukan adanya korelasi.

Saran bagi responden di SMAN 3 Surabaya adalah mempertahankan asupan protein seperti daging, ayam, bebek, telur, ikan, kerang serta vitamin C seperti jambu biji, jeruk, pepaya, dan tomat. Selain itu meningkatkan asupan makanan seperti daging, ayam, hati, telur, dan ikan yang mengandung zat besi heme untuk mencegah terjadinya anemia. Saran bagi sekolah adalah berkoordinasi dengan tenaga kesehatan di puskesmas setempat untuk mengadakan pemeriksaan kadar hemoglobin secara rutin.

\section{ACKNOWLEDGEMENT}

Ucapan terima kasih disampaikan kepada Kepala Sekolah SMAN 3 Surabaya dan Kepala Humas SMAN 3 Surabaya yang telah memberikan ijin melaksanakan penelitian di SMAN 3 Surabaya, kepada siswi kelas X dan XI yang telah bersedia menjadi responden penelitian, serta bidan yang telah membantu penelitian dalam pengambilan darah responden.

\section{REFERENSI}

1. Adriani, M. \& Wirjatmadi, B. Peranan Gizi dalam Siklus Kehidupan. (Kencana, 2016).

2. Arisman. Gizi dalam Daur Kehidupan. (EGC, 2009).

3. Gibney, M. J., Margetts, B. M., Kearney, J. M. \& Arab, A. Gizi dan Kesehatan Masyarakat. (EGC, 2009).

4. Adriani, M. \& Wirjatmadi, B. Pengantar Gizi Masyarakat. (Kencana, 2014).

5. Heather, A. E. M., April, C. M., Connie, M. W., GP, M. \& CJ, B. Food Insecurity is Associated With Iron Deficiency Anemia in US Adolescents. Am. J. Clin. Nutr. 90, 1358-1371 (2009).

6. Pradanti, C. M., M, W. \& K, H. S. Hubungan Asupan Zat Besi (Fe) dan Vitamin C dengan Kadar Hemoglobin pada Siswi Kelas VIII SMP Negeri 3 Brebes. J. Gizi 4, 24-49 (2015).

7. Almatsier, S. Prinsip Dasar IImu Gizi. (Gramedia Pustaka Utama, 2009).

8. Nurlaila, H., Hazanah, S., Shoufiah, R. \& Poltekkes Kemenkes Kaltim. Hubungan Stres Dengan Siklus Menstruasi Pada Mahasiswa Usia 18-21 Tahun. J. Husada Mahakam III, 452-521 (2015).

9. Maryana. Gizi Reproduksi. (Pustaka Rihana, 2012).

10. Wliyati \& Riyanto. Faktor Terjadinya Anemia Remaja Putri di SMA Negeri Kota Metro. J. Kesehat. Masy. Tanjungkarang 5, (2012).

11. Balitbangkes, R. I. Riset Kesehatan Dasar 2013. (Kementerian Kesehatan RI, 2013).

12. Setyono, F. S. Hubungan Tingkat Pengetahuan Gzi, Body Image, dan Tindakan Diet dengan Status Gizi Remaja Putri. (Universitas Airlangga, 2010).

13. Ditjen Bina Gizi. Rencana Aksi Pembinaan Gizi Masyarakat (RAPGM) Tahun 2010-2014.

(Kemenkes RI, 2011)

14. Permatasari, W. Hubungan antara status gizi, siklus dan lama menstruasi dengan kejadian 
dengan Siklus Menstruasi pada Remaja Putri di SMA Negeri 1 Imogiri, Bantul, Yogyakarta. J. Stud. Pemuda 3, 33-38 (2013).

26. Shariff, S. A. \& Akbar, N. Window of Health, Vol . 1 No . 1 ( Januari 2018 ) Hubungan Antara Status
Gizi Dan Pola Menstruasi Dengan Kejadian Anemia Pada Mahasiswi 34 | Penerbit : Pusat Kajian dan Pengelola Jurnal Fakultas Kesehatan Masyarakat Universitas Muslim Indonesia Window of. 1, 34-39 (2018). 